\title{
Neutrality in Austria's Foreign and Security Policy after the Cold War
}

\begin{abstract}
After the end of the Cold War, neutrality was redefined by adapting its functioning to the unprecedented changes in the international environment. This redefinition covered two key areas; the change in attitudes towards international conflicts and the rejection of the principles of economic neutrality. By joining the EU, Austria, as a perpetually neutral state, made a commitment to fully conform with its obligations arising from participating in the Common Foreign and Security Policy. The necessary changes to legal regulations have led to a departure from the principles of traditional neutrality and the actual change of international status to an alliance-free/post-neutral state.

The main area of main Austrian political forces' dispute within foreign and security policy was the recognition of the possibility of abandonment of neutrality and NATO membership. It remains unresolved as to whether the rejection of neutrality constitutes solely a legal and constitutional issue. At the same time, Austrian society, with its firm pro-European attitude, still shows a strong commitment to neutrality.
\end{abstract}

Keywords: Austria, Perpetual Neutrality, Freedom from Alliances, Post-Neutrality, Foreign and Security Policy, European Union

\section{Introduction}

In May 2020, Austria will celebrate the 65th anniversary of regaining its sovereignty. It will be tantamount the lapse of 65 years since the establishment of perpetual neutrality of the country, however, it may be expected that this aspect will not be particularly exposed during the

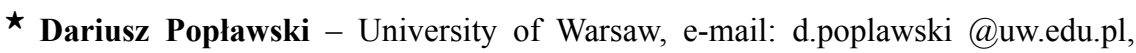
ORCID: 0000-0003-1901-5213. 
celebration. The state recognized as Hitler's first victim had factually become a hostage to the growing divergences between the East and the West. In exchange for adopting the international status modelled on Switzerland, Austria returned to the international community and, in accordance with the provisions of the preamble to the State Treaty of 1955, joined the UN. Initially, the country's foreign policy encountered serious barriers related to unregulated relations with its neighbours and complicated international situation.

During the Cold War, Austria was perceived primarily through the prism of the so-called active neutrality policy of the 1970s, which led to the strengthening of the international position of the state as a political bridge between the East and the West. In the mid 1980s, Austria moved to the tracks of the so-called realistic neutrality policy. In addition to a significant reduction in the scope and intensity of international activity, a strong trend to quickly resolve the issue of European integration was noticeable in that time. Taking into account the actual balance of political forces and the deep attachment of society to the international status of the country, in 1989 the Austrian government applied for membership in the European Community, emphasizing at the same time the status of perpetual neutrality.

The purpose of the article is to present the evolution of the significance of neutrality in Austria's foreign security policy after the Cold War. The article verifies the hypothesis indicating the possibility of effective rejection of neutrality in a foreseeable time perspective. The analysis takes into account the main internal and international conditions affecting Austrian neutrality/post-neutrality.

\section{Redefining Austria's Neutrality after the Cold War}

It seems reasonable to believe that, in addition to rejecting economic neutrality, the new approach to armed conflicts has changed the neutrality paradigm following the Cold War. Until then, all conflicts were treated as wars in the classical sense, where the law of neutrality might be applied. ${ }^{1}$ In the ongoing debate, it was pointed out that the neutral states functioned in a dual legal reality and, in fact, the existence of the two overlapping systems was accepted. The first was based on the universally binding prohibition of wars, while the second was related to the application of

1 Such interpretation is strongle related to the post-war Swiss practice, which is the effect of moving away from UN membership and progressive dogmatization of the principles of neutrality policy. D. Popławski, Szwajcarska polityka bezpieczeństwa (Swiss Security Policy), Wydawnictwo Naukowe Scholar, Warszawa 2007. 
the law of neutrality derived from traditional law of war. This situation constituted a serious complication, especially for Austria, as a neutral member of the UN. From the point of view of international law, this was undoubtedly an unsatisfactory situation, but at the same time it created some opportunities for the functioning of the neutral state at the UN forum.

The new approach to armed conflicts, also known as 'Verdross doctrine', called for the primacy of 'the UN law' over the law of neutrality. ${ }^{2} \mathrm{~A}$ dualistic approach was introduced with the aim to distinguish between war in the traditional meaning and conflict in the meaning of the United Nations Charter. As soon as the UN is involved in a conflict, the law of neutrality ceases to apply. In the event of a conflict without the participation of the $\mathrm{UN}$, its norms may be applied. Adoption by the governments of neutral states assumptions of the new concept also marked a breakthrough in the field of participation in the implementation of UN military sanctions. ${ }^{3}$

The necessity to make fundamental decisions in the spirit of the new interpretation of neutrality came forward much faster than expected. There was significant pressure from current developments connected with the Yugoslavian crisis as well as the war in Iraq. Austria found itself in a particularly difficult situation, being directly threatened by the dynamic development of the situation in the Balkans. The conflict in the Persian Gulf also brought many problems after the UN Security Council asked for support for military and economic sanctions against Iraq. By introducing the necessary regulations in an accelerated manner, Austrian neutrality was subordinated to UN decisions. It was the result of applying in practice Verdross doctrine. ${ }^{4}$

2 The precursor of the new approach was Alfred Verdross who in the mid 1980s did not recognize UN coercive measures as acts of war and treated the law of war as not applicable in such cases; A. Verdross, B. Simma, Universelles Völkerrecht (Universal international law), Duncker \& Hublot, Berlin 1984, p. 148; Karl Zemanek advocated the law of neutrality not being applied because of the expectations of the international community. K Zemanek, The Changing International System A New Look a the Collective Security and Permanent Neutrality, "Austrian Journal of Public and International Law", no. 42/1991.

3 See: D. Schindler, Sieben Thesen zur Neutralität (Seven theses on neutrality), in: Sicherheitspolitik der Schweiz nach dem Jahrestausenden. Sieben Thesen zur künftigen Selbstbehauptungsstrategie der Schweiz (Switzerland's security policy after millennia. Seven theses on Switzerland's future self-assertion strategy), ed. G.G. Heliberger, Zürich 1997, pp. 30-31.

4 A further consequence of these activities was sending Austrian contingent to the border region between Iraq and Kuwait and (in December 1995) dispatching mechanized transport unit under IFOR peacekeeping forces in Bosnia and Herzegovina. On the other hand, NATO considered its intervention in Kosovo justified but refused to allow transit flights of aircrafts from NATO countries. In the justification for this decision, the issue of 
The second key component of the redefinition of neutrality was rejection of economic neutrality, which paved the way for broad involvement in the European integration process. Since the very beginning of its existence, the European Union has not spoken clearly about the compatibility of the principles of neutrality with membership. ${ }^{5}$ The official statements emphasized that it is the applicant state that should decide for itself whether membership is compatible with obligations arising from its international legal status. However, Austria's neutrality was perceived in a particular way in Brussels. First of all, Austria had been showing a significant gravity towards the European Communities long before, which distinguished it among other neutral countries of the European Free Trade Association (EFTA). ${ }^{6}$ However, its formal status of perpetual neutrality was also of importance, as it constituted a significant obstacle for some member states.

Austria's actions aimed at rejection of the concept of economic neutrality received understanding of Brussels. At the end of the 1980s, the opinions in Austriawere increasingly heard that the law of neutrality should not constitute an obstacle to rejecting traditional principles of economic neutrality. In fact, there were few economic norms that were difficult to be defined within the law of neutrality, which could be reduced to just few principles. The Hague Conventions clearly distinguished between permitted economic support and prohibited military support. However, as the totalitarian nature of wars was progressing, the distinction was becoming increasingly unjustified. Just like those related to trade in war materials by state-owned and private companies, which was only allowed for the latter. Taking into account contemporary conditions in the field of arms control and steering arms export, it was questioned whether such division makes sense at all. ${ }^{7}$

the initial lack of UN mandate was pointed out as well as the fact that from the formal and legal points of view, it was a NATO mission and not a EU mission. During the Iraqi crisis, the US efforts to obtain permission for flights of combat aircrafts over Austrian territory did not succeed. This was justified by the lack of a UN mandate A. Skuhra, Österreichische Sicherheitspolitik (Austrian security policy), in: Politik in Österreich. Das Handbuch (Politics in Austria. The handbook), eds. H. Dachs, P. Gehrlich H., Gottweiss, H. Kramer, V. Lauber, W.C. Müller, E. Talos, Manz, Wien 2006, p. 856.

5 For more on the impact of the Community on European neutrality see: M. Gehler, R. Steiniger, Die Neutralen und die europäische Integration 1945-1994 (The Neutral and European Integration 1945-1994), Institut für die Zeitgeschichte der Universität. Arbeitskreis Europäische Integration, Historische Forschungen, Veröffentlichungen 3, InnsbruckWien-Köln-Weimar 2000.

6 D. Popławski., Austriacka polityka neutralności (1955-1995) [Austrian Policy of Neutrality (1955-1995)], Wydawnictwo Naukowe, Warszawa 1995.

${ }^{7}$ A.R Schaub, Neutralität und kollektive Sicherheit: Gegenüberstellung zweier unvereinbarer Verhaltenskonzepte in bewaffneten Konflikten und These zu einem völkerrechtsge- 
The above arguments were part of a broad critique of the concept of economic neutrality and the progressing process of demythologizing the relationship between law and neutrality policy. It was also pointed out that the principles of economic neutrality were actually formulated on the basis of post-war Swiss doctrine and that the decisions on their application taken by Austria had a political dimension. It was argued that giving up their application should have the same nature. ${ }^{8}$

\section{Austria's Neutrality Towards the Evolution of the EU Security Policy}

By joining the EU in 1995, Austria was able to demonstrate many actions evidencing its willingness to engage in broadly understood common activities and to strengthen the crisis prevention and crisis management capabilities. First of all, it was about the basic regulations enabling dispatch of Austrian army units and individuals abroad. The new solution opened the way not only, as it had been so far, to activities within the UN but also within the EU and the OSCE. This regulation was interpreted in the context of freedom of decision making when introducing further changes related to Austrian neutrality.

The adjustment activities adopted were perceived as the necessary minimum associated with the EU membership and the resulting obligations in the field of foreign and security policy. In the absence of full knowledge of further development of the situation in this area and in light of the divergences on this matter between large member states, Austria adopted the assumptions of the so-called double strategy. Full compliance was declared within the second pillar of the EU, while rejecting the possibility of extending the scope and intensity of militarydefence functions at the same time. ${ }^{9}$

mässen modus vivendi. Schriftenreihe des Institutes für Internationales Recht und Internationale Beziehungen (Neutrality and collective security: juxtaposition of two incompatible behavioral concepts in armed conflicts and thesis on a modus vivendi in accordance with international law. Publication series of the Institute for International Law and International Relations), Juristische Fakultät der Universität Basel, Basel, Frankfurt am Mein, 1995.

8 W. Hummer, M. Schweizer, Österreich und EEC. Neutralitätsrecht Beurteilung der Möglichkeit der Dynamisierung der Verhältnisse zur EEC (Austria and EEC. Neutrality law Assessment of the possibility of dynamizing relations with the EEC), Signum, Wien 1987, p. 304.

9 Cf. P. Schmidt, Die neuen EU - Mitglieder Finnland, Österreich und Schweden, vor der Regierungskonferenz 1996. Sicherheitspolitische Ambivalenzen (The new EU members Finland, Austria and Sweden, before the 1996 IGC. Security policy ambivalences), Stiftung Wissenschaft und Politik, Ebenhausen 1995, p. 15. 
Visible tensions between neutrality and the EU membership emerged when the Amsterdam Treaty outlined the prospects for the integration of the Western European Union (WEU) and the EU. Participation in Petersburg tasks and cooperation in the field of arms arouse many doubts. At the same time, however, a broad debate on the matter pointed to the existence of protective mechanisms ${ }^{10}$ enabling the functioning of a neutral state within the EU. As a result of a political compromise between the main political forces of the country, a reservation was made, when ratifying the Amsterdam Treaty, regarding the need for a UN mandate for peacekeeping missions in which Austria would participate and the prohibition of active participation in peace-restoring operations was maintained.

The adaptation steps made in accordance with the new interpretation of neutrality did not, in essence, violate its basic substance, i.e. maintaining a neutral attitude in specific cases. Fundamental changes in this area were to take place along with the amendment of the constitution in 1999. It enabled participation in peace supporting operations within the EU and the Partnership for Peace (PfP). The amendment had also a doctrinal dimension, as it confirmed that Austria was not obliged to adopt neutral attitude in individual cases. This meant that the constitutional component of perpetual neutrality in the form of unconditional refraining from participating in armed conflicts actually disappeared. After the amendment, only the political option of neutral attitude has remained, but this is a completely different instrument than the general commitment to permanent neutrality. ${ }^{11}$ The essence of these changes lies in the relativization of the principle of absolute prohibition of neutral state's participation in war, while maintaining the prohibition of its membership in military pacts and joint defence. The main result of these regulations was the factual change of Austria's international status to a alliance-free state (nonalliance/post-neutral). The territorial aspect was also significant in this

10 D. Popławski, Między bezstronnościa a solidarnościa międzynarodowa. Polityka bezpieczeństwa europejskich państwa neutralnych i bezaliansowych po zimnej wojnie (Between Impartiality and International Solidarity. Security Policy of a European Neutral and Non-alligned Countries after the Cold War), Wydawnictwo Naukowe Scholar, Warszawa 2013, pp. 109-110.

11 W. Hummer, Solidarität versus Neutralität. Das immerwährend neutrale Österreich in der GASP vor und nach Nizza (Solidarity versus neutrality. The always neutral Austria in the CFSP before and after Nice), „Österreichische Militärische Zeitschrift“, no. 2/2001, p. 153; S. Grillier, Die GASP und das Ende immerwährende Neutralität (The CFSP and the end of permanent neutrality), in: Rechtsfragen in der Anwendung des Amsterdamer Vertrages (Legal issues in the application of the Amsterdam Treaty), ed. W. Hummer, Manz, Wien 2001, p. 271. 
case. The solutions adopted referred only to the EU area, while outside the EU the traditional obligations resulting from neutrality would still apply. Such approach was often reduced to the slogan: 'Solidarity with Europe, neutrality in wars outside Europe'. ${ }^{12}$

In the atmosphere of criticism from Brussels and diplomatic sanctions, ${ }^{13}$ the centre-right coalition of the Austrian People's Party (ÖVP) and the Freedom Party of Austria (FPÖ) started works on a new concept of Austrian security and preparation of a new defence doctrine. In the initial period of development the CSDP of the EU, Austrian society was very positive about it as well as about the plans to create a European army. In 2002, the vast majority of Austrians (73\%) supported such a solution. ${ }^{14}$ This situation created a favourable climate for the regulations being implemented.

New defensive doctrine from $2001^{15}$ was based on the concept of preventive measures used instead of reacting to existing threats. In fact, the principle of European solidarity has replaced the current concept of security policy. Austria's orientation in the field of security policy was defined as an alliance-free state (Bündnissfrei). The term 'neutrality' was not used in the document.

Undoubtedly, the Lisbon Treaty constituted another challenge for further positioning of Austrian neutrality. However, an unequivocal assessment of the importance of new regulations proved to be difficult to carry out. Certainly, the Lisbon Treaty threatened neutrality to much greater extent than the Nice Treaty. While the former suggested that the CSDP may lead to joint defence, the latter unequivocally stated that the common defence policy leads to joint defence, provided that the European Council so decides. It is undisputed at the same time, that common defence is incompatible with neutrality, irrespective of how neutrality is

12 H.P. Neuhold., Comments on the Austrian Position, in: Challenges to Neutral and Non-Aligned Countries in Europe and Beyond, ed. E. Munro, Centre for Security Policy, Geneva 2004, p. 14.

${ }^{13}$ Cf. W. Hummenr, A. Pelinka, Österreich unter 'EG-Quarantäne'. Die 'Massnahmen der 14' gegen die österreichische Bundesregierung aus Politik wissenschaftlichen und juristischer Sicht. Chronologie, Kommentar, Dokumentation (Austria under ,EC-Quarantine'. The 'measures of the 14' against the Austrian federal government from a scientific and legal perspective. Chronology, commentary, documentation), Linde, Wien 2002.

14 P. Schmidt, J. Edthofer, Die EU ALS Sicherheits- und Verteidigungsunion: Das Meinungsbild der ÖsterreicherInnen im Vergleich (The EU as a security and defense union: the opinion of Austrians in comparison), "ÖGIE. Policy Brief", no. 20/2018.

15 Sicherheits- und Verteidigungsdoktrin. Analyse-Teil. Bericht an der Nationalrat (Security and Defense Doctrine. Analysis part. Report to the National Council), Verfasst von einer Expertenkommission im Auftrag der Bundesregierung 23.01.2001, Wien 2002. 
interpreted. It should be noted that also in the case of the Lisbon Treaty Austria has referred to its specific safeguard clauses.

First of all, the clauses include the possibility of abstaining from vote, in connection with the so-called second Irish clause, which ensures protection for the specific nature of the security and defence policy of the Member States. However, this clause is sometimes interpreted as the possibility offull exclusion of neutral and non-allied states from regulations applying to alliances. This is not only a far-reaching simplification, but it also does not correspond to the intentions of these countries, in particular those of Austria, ${ }^{16}$ which has consistently advocated introduction of such regulations.

Undoubtedly, a more favourable interpretation for Austria constitutes the concept of the so-called asymmetrical alliance commitments creating rights for neutral states and obligations for other EU members. This interpretation seems closer to reality. Thus, in specific cases, a neutral solidarity should be expected from neutral states, but not 'blind solidarity'. ${ }^{17}$ Such expectations might be formulated on the basis of the first words of Article 42 item 7 regarding assistance with all available means. Obligations arising from neutrality may in this case constitute restriction of freedom of action.

There are also opinions that, despite the existence of protective mechanisms, Austria's continued persistence in relation to its neutral status will lead in a long-term not only to the deficit of legitimacy and loss of credibility among EU members, but also to serious challenges for the country in the area of security policy. ${ }^{18}$ However, it seems that it is not the status itself, which has been modified by subsequent amendments to the constitution, that is the source of the above mentioned problems. The dangers presented are mainly caused by the discrepancies between the declarations of successive Austrian governments and the actual actions taken in the field of security policy.

16 During negotiations on the constitutional treaty, the ÖVP-FPÖ government consistently advocated the introduction of the alliance clause. Chancellor Schüssel said that the solution proposed by France, Germany and Great Britain is consistent with neutrality. Ultimately, Vienna had to withdraw from this position and supported Finland's initiative to loose the general alliance clause and to rely to greater extent on the so-called Irish clause.

17 P. Hipold, Österreichs Neutralität nach Lissabon (Austria's neutrality after Lisbon), „Juristen Zeitung“, July 2010, p. 594.

18 U. Kranenpohl, A. Opitz, „Entaustrifizierte” Neutralität: Rechtspolitische Wandelder österreichischen Aussen- und Sicherheitspolitik seit dem Ende des Kalten Krieges (,Deaustrated“ neutrality: Legal policy change in Austrian foreign and security policy since the end of the Cold War), in: Im Dienst der internationalen Gemeinschaft-Österrech in der Vereiten Nationen (In the service of international community law in the United $\mathrm{Na}$ tions), ed. J. Troy, Institut für Politikwissenschaft Innsbruck, Innsbruck 2013, p. 73. 
The centre-right coalition was unequivocally considered as the first government that presented a coherent view on Austria's attitude towards NATO and the new defence policy within the EU. The thesis was also promoted that Austria should become a top leader in the field of structured cooperation in order to belong to the avant-garde of the EU security policy from its very launching. It was emphasized that due to technical and logistical problems it would be advisable to join the battle group with the Czech Republic and Germany. As it turned out later, these plans were too far-reaching and Austria withdrew from this idea. The decision to purchase combat aircrafts in 2008 changed the situation only to little extent.

Declarations on the continuation of the armed forces reform and the purchase of new equipment should certainly be treated as an expression of constant improvement of combat capabilities in the context of the Lisbon Treaty. The new Security Strategy finally adopted in 2013 clearly dominates the comprehensive approach to security, covering its most important aspects, dimensions and institutions as well as explicitly relating to the principles of European solidarity.

However, the practical implementation of these assumptions faces numerous barriers. Undoubtedly, one of the important reasons of the legitimacy deficit was the systematically limited defence budget, which in 2009 was still far from 1\% of GDP. Problems were becoming increasingly apparent and in 2014 media informed that Austrian army was on the verge of bankruptcy. The budget subsidy did not exceed $0.5 \%$ of GDP. The third ÖVP/FPÖ coalition government has put a clear emphasis on restoring Austrian defence capabilities, which had been largely neglected. At the same time, an increasing engagement in the area of CSDP might be observed together with clear profiling of Austrian activity in the area of crisis management. ${ }^{19}$

The actions taken did not convince sceptics who continue to accuse Austria of 'free-riding' and taking advantage of neutrality in order not

19 In official publications from 2019, three areas of activity were indicated. First of all, the involvement within the Permanent Structured Cooperation was emphasized, including participation in 4 projects together with France, Croatia, Slovenia and Hungary, among them - in the one related to effective protection against chemical, biological and radiological war materials. As a response to insufficient protection of the EU borders, about 1,000 soldiers were sent with the intention to be a formation assisting the police in protecting Austrian borders. The third area was participation of approximately 1,000 soldiers in 14 foreign missions and over 300 soldiers staying in constant readiness. Thus, well over 2,000 soldiers permanently perform assigned tasks in the above area; Sicher. Und morgen? Sicherheitspolitische Jahresbericht 2019 (For sure. And tomorrow? Security policy annual report 2019), Direktion für Sicherheitspolitik. Bundesministerium Landesverteidigung, Wien 2018, pp. 8-9. 
to take more responsibility for security at the EU level. ${ }^{20}$ As an initiative enabling alleviating Austria's credibility deficit abroad may be perceived, announced in July 2019, project of establishing the Civil Peace Service (Ziviler Friedensdienst) as a new foreign policy instrument. Modelled on German solutions, it would allow for the introduction of various methods of civil conflict management, which in a concrete way contribute to overcoming violence, constructive and peaceful transformation of conflicts and protecting individuals against violence and human rights violations. Its goal should be long-lasting peace and reconciliation. The project was included in the new government agenda. ${ }^{21}$

\section{The Perspective of Rejecting Neutrality}

The end of the Cold War and the collapse of the USSR's activated on the Austrian political scene forces openly calling for the rejection of neutrality and accession to NATO. ${ }^{22}$ Observation of Austrian political sphere made it possible for the author to conclude that during the rule of the ÖVP-FPÖ government coalitions, these demands increased, whereas the governments of the great coalition ÖVP-SPÖ were characterized by seeking compromise solutions, consisting in full compliance with obligations arising from participation in the CSDP, while neutralizing the endeavours to join NATO.

Modification of Austria's international status into 'freedom from alliances' at the beginning of the 21 st century does not change its obligations regarding membership in military alliances. However, mainly in the area of foreign and security policy, one can still find specific relations between traditionally perceived neutrality and postneutrality. Austrian government, without directly referring to the formal international law status in a specific area, continued to implement the policy of neutrality, e.g. with regard to armed conflicts, in the absence of a UN position.

${ }^{20}$ H. Kramer, G. Matzner, P. Steyrer, Türkis-Blaue Aussen- und EU-Politik. Was wir zu erwarten haben (Turquoise-blue foreign and EU policies. What we can expect), „International- Die Zeitschrift für internationale Politik", no. 1/2018.

21 P. Hämmerle, T. Roithner, Ziviler Friedensdienst als Instrument österreichischen Aussenpolitik. Zwischenbilnas der Kampanigne (Civil peace service as an instrument of Austrian foreign policy. Interim balance of the campaign), Internationaler Versöhnungsbund, https://versoehnungsbund.at/zwishenbilanz-ziviler-friedensdinst (access 17.02.2020).

22 In the 1990 election campaign, FPÖ leader Jörg Haider argued that neutrality imposed on Austria is not justified in post-Cold War conditions. This radical view was not widely supported among Austrian society attached to the country's neutrality status. However, FPÖ in its 1997 election program was clearly in favour of the NATO membership. 
Although there could be many indications that today we can speak of Austria's perpetual neutrality only in a normative aspect, the very idea of neutrality is still present in the political life of the country. In general, it may be observed that most members of Austria's political elite are in favour of abandoning the traditional, broad formula of neutrality, which is identified with the Cold War period. Thus, Austria has abandoned the 'holistic view of neutrality in favour of its narrow interpretation'. ${ }^{23}$ First of all, it should be taken into account that in the broad public perception freedom from alliances/non-alignment is very often considered as a modified concept of neutrality, adapted to post-Cold War conditions and the EU membership.

The ÖVP/FPÖ coalition governments, deleting neutrality from public space, assumed that rejection of neutrality is a purely legal issue. They argued that the hitherto modification of neutrality in the constitution had not been called into question by the UN Security Council or by countries that were notified of obligations regarding perpetual neutrality. Also when the so-called military articles of the State Treaty had been modified, its signatories did not raise any objections. Thus, it was recognized that the sovereign shaping of relations with other countries was not prevented by the international law restrictions created by the State Treaty. Based on the above premises, the federal government and some experts have been treating actions, not only related to modification but also to hypothetical abolition of neutrality, as lying within the exclusive competences of state authorities. $^{24}$

There exists also a different point of view. A significant part of Austrian international law experts emphasize that in the international sense Austria is obliged to respect its neutrality because it was established by an international law act. Thus, it cannot be terminated unilaterally. Some representatives of Austrian international law doctrine also take the view that even if the government managed to obtain required majority to remove the constitutional bill on perpetual neutrality, the international legal status of the state would not be completely changed.

Bearing in mind the diverse opinions present in Austrian international law doctrine and the polarization of positions of the country's major

23 J.L. Beyer, S.C. Hofmann., Varieties of neutrality: Norm revision and decline, "Cooperation and Conflict", no. 3/2001, p. 303; C. Gebhard, Is Small Beatiful? The Case of Austria, "Swiss Political Science Review", no. 9/2013, p. 17, https://onlinelibrary.wiley. com/doi/fuul/10.1111/spsr.12042 (access 17.02.2020).

24 J. Niederberger, Österreichische Sicherheitspolitik zwischen Solidarität und Neutralität (Austrian security policy between solidarity and neutrality), „Bulletin 2001 zur Schweizerischen Sicherheitspolitik“ 2001, p. 78. 
political forces, the significant attachment of Austrian society to the idea of neutrality remains an important factor. The trends from the beginning of the 21 st century, indicating a systematic decline in the importance of neutrality for the Austrians, have not persisted. ${ }^{25}$ At the same time, most respondents still support CSDP, although this support has been present since 2015 below the EU average (in 2018 - at the level of 57\% with the EU average of 75\%). This also means that in the public perception, CSDP development trends are generally not perceived as a threat to neutrality/ post-neutrality.

The removal of neutrality from public space, characteristic of the early 21 st century, has clearly decreased in the second decade of the current century. In the Security Strategy of 2013 reference was made to the legal and constitutional basis of perpetual neutrality. Among the principles that should guide Austrian foreign and security policy were active intermediation in international conflicts and maintaining mediation capabilities resulting from 'Austria's position as both the EU member and a neutral state'. ${ }^{26}$

Taking into account both the internal and international aspects, it should be pointed out that modern neutrality analyzes are clearly shifting from law to politics. Therefore, any formal rejection of perpetual neutrality should also be seen in the context of the political will of accepting this fact by the states concerned, in particular the signatories of the State Treaty. Russia would undoubtedly play a significant role in this process. In the Kremlin's view, relations between the two countries have been characterized by stability, predictability and lack of significant problems, and Austria is perceived in the categories of a 'friendly pragmatist'. ${ }^{27} \mathrm{At}$ the same time, however, Russia recognizes that the rejection of neutrality would be associated with Austria's accession to NATO, in whose enlargement it is not in the slightest interested.

${ }^{25}$ Opinion polls conducted in February 2019 show that neutrality is still important for $80 \%$ of Austrians (56\% - very important, 24\% - rather important, $11 \%$ - rather not important, $5 \%$ - not important). Regarding the creation of a European army, Austria is in the group of five EU countries where minority is in favor of such a solution (2017 - 45\%). The clearly outlined skepticism of the majority of the population has its source, among others, in a critical assessment of the EU military strength in the global ranking, which is deemed insufficient. M. Mohr, Wichtigkeit der Neutralität In Österreich (Importance of neutrality in Austria), 2019, https:/de.statista.com/statistik/daten/studie/992825/umfrage/ wichtigkeit-der-neutralitaet-in-oesterreich/ (access 14.12.2019).

26 Österreichische Sicherheitsstrategie. Sicherheit in einer neue Dekade-Sicherheit gestalten (Austrian security strategy. Shaping security in a new decade), Bundeskanzleramt, Wien 2013, pp. 8, 20.

${ }_{27}$ M. Raś, Austria w polityce zagranicznej Federacji Rosyjskiej (Austria in the Foreign Policy of the Russian Federation), "Studia Politica Germanica" 2014, p. 165. 
It should be noted that recently, in the context of relations with Russia, the importance of neutrality/post-neutrality as a political attitude enabling the extension of the diplomatic instruments of a small state has been again recognized in the political circles of Austria. Vienna aspires to act as an intermediary between Russia and the European Union. Austrian press presents historical parallels comparing today's situation to Kreisky's activity towards the Palestine Liberation Organization. ${ }^{28}$ Austria is trying to play a similar role in disputes between Brussels and the Visegrad Group countries. Undoubtedly, there are some analogies to the active policy of neutrality of the Cold War period, which has been a trademark of Austrian foreign policy. Although the circumstances of such a policy are quite different, Austria sees in such international activity a possibility of strengthening its role and significance within the European Union. This is favoured by the sentiments in Austrian society, where the predicted erosion of the importance of neutrality has not occurred.

\section{Conclusions}

Submission of application for the EU membership in 1989 constitutes a symbolic date of breaking the traditional principles of neutrality and joining the processes of European integration. The redefinition of neutrality that has been taking place in the 1990s has decisively enabled membership in the community and a change in attitude towards armed conflicts. In accordance with the commitments made, the difficult process of adapting legal regulations to the requirements of membership was initiated, in particular as regards the possibility of full participation in cooperation in the field of the CFSP. As a result, Austria shifted to the position of an alliancefree state. However, the constitutional bill on perpetual neutrality of 1955 is still in force, and is unlikely to be overruled in the foreseeable future.

Since the end of the Cold War, the process of polarization of the Austrian political scene around the question of rejecting perpetual neutrality and joining NATO has progressed. ÖVP/FPÖ governments were proponents of the rejection of neutrality, while the great ÖVP/ SPÖ coalitions accepted compromise solutions. At the same time, the process of eliminating neutrality from public sphere has been clearly noticeable. Within the society, the idea of neutrality is still present. The freedom from alliances formula is understood by a significant number of Austria's citizens as a modified neutrality, adapted to modern conditions. It remains unclear whether the hypothetical rejection of neutrality lies

28 „Der Standard“, 19.02.2019. 
within the exclusive competence of state authorities. Despite numerous declarations of significant commitment to the development of the CSDP, and in particular Permanent Structured Cooperation, Austria's activities in this area have been far from sufficient.

\section{References}

Beyer J.L., Hofmann S.C., Varieties of neutrality: Norm revision and decline, "Cooperation and Conflict", no. 3/2001.

"Der Standard", 19.02.2019.

Gebhard C., Is Small Beatiful? The Case of Austria, "Swiss Political Science Review", no. 9/2013, p. 17, https://onlinelibrary.wiley.com/doi/fuul/ 10.1111/spsr.12042 (access 17.02.2020).

Gehler M., Steiniger R., Die Neutralen und die europäische Integration 19451994 (The Neutral and European Integration 1945-1994), Institut für die Zeitgeschichte der Universität. Arbeitskreis Europäische Integration, Historische For-schungen, Veröffentlichungen 3, Innsbruck-WienKöln-Weimar 2000.

Grillier S., Die Gasp und das Ende immerwährende Neutralität (The CFSP and the end of permanent neutrality), in: Rechtsfragen in der An-wendung des Amsterdamer Vertrages (Legal issues in the application of the Amsterdam Treaty), ed. W. Hummer, Manz, Wien 2001.

Hämmerle P., Roithner T., Ziviler Friedensdienst als Instrument österreichischen Aussenpolitik. Zwischenbilnas der Kampanigne (Civil peace service as an instrument of Austrian foreign policy. Interim balance of the campaign), Internationaler Versöhnungsbund, https://versoehnungsbund.at/ zwishenbilanz-ziviler-friedensdinst.

Hipold P., Österreichs Neutralität nach Lissabon (Austria's neutrality after Lisbon), „Juristen Zeitung“, July 2010.

Hummer W., Pelinka A., Österreich unter „EG - Quarantäne. Die „Massnahmen der 14“ gegen die österreichische Bundesregierung aus Politik wissenschaftichen und juristischer Sicht. Chronologie, Kommentar, Dokumentation (Austria under 'EC - Quarantine'. The 'measures of the 14' against the Austrian federal government from a scientific and legal perspective. Chronology, commentary, documentation), Linde, Wien 2002.

Hummer W., Solidarität versus Neutralität. Das immerwährend neutrale Österreich in der GASP vor und nach Nizza (Solidarity versus neutrality. The always neutral Austria in the CFSP before and after Nice), „Österreichische Militärische Zeitschrift“, no. 2/2001.

Hummer W., Schweizer M., Österreich und EWG. Neutralitätsrecht Beurteilung der Mög-lichkeit der Dynamisierung der Verhältnisse zur EWG 
(Austria and EEC. Neutrality law Assessment of the possibility of dynamizing relations with the EEC), Signum, Wien 1987.

Kramer H., Matzner G., Steyrer P., Türkis-Blaue Aussen- und EU-Politik. Was wir zu erwarten haben (Turquoise-blue foreign and $E U$ policies. What we can expect), „International - Die Zeitschrift für internationale Politik“, no. 1/2018.

Kranenpohl U., Opit A., „Entaustrifizierte” Neutralität: Rechtspolitische Wandelder österreichischen Aussen- und Sicherheitspolitik seit dem Ende des Kalten Krieges ("Deaustrated" neutrality: Legal policy change in Austrian foreign and security policy since the end of the Cold War) in: Im Dienst der internationalen Gemeinschaft-Österrech in der Vereiten Nationen (In the service of international community law in the United Nations), ed. J. Troy, Institut für Politikwissenschaft Insbruck, Insbruck 2013.

Mohr M., Wichtigkeit der Neutralität In Österreich (Importance of neutrality in Austria), 2019, https://de.statista.com/statistik/daten/studie/992825/ umfrage/wichtigkeit-der-neutralitaet-in-oesterreich/ (access 14.12.2019).

Neuhold H.P., Comments on the Austrian Position, in: Challenges to Neutral and Non-Aligned Countries in Europe and Beyond, ed. E. Munro, Geneva Centre for security Policy, Geneva 2004.

Niederberger J., Österreichische Sicherheitspolitik zwischen Solidarität und Neutralität (Austrian security policy between solidarity and neutrality), „Bulletin zur Schweizerischen Sicherheitspolitik“ 2001.

Österreichische Sicherheitsstrategie. Sicherheit in einer neue Dekade-Sicherheit gestalten (Austrian security strategy. Shaping security in a new decade), Bundeskanzleramt, Wien 2013.

Popławski D., Między bezstronnościq a solidarnościq międzynarodowq. Polityka bezpieczeństwa europejskich państwa neutralnych i bezaliansowych po zimnej wojnie (Between Impartiality and International Solidarity. Security Policy of a European Neutral and Non-alligned Countries after the Cold War), Wydawnictwo Naukowe Scholar, Warszawa 2013.

Popławski D., Szwajcarska polityka bezpieczeństwa (Swiss Security Policy), Wydawnictwo Naukowe Scholar, Warszawa 2007.

PopławskiD.,Austriacka polityka neutralności(1955-1995) [Austrian Neutrality Policy (1955-1995)], Wydawnictwo Naukowe Scholar, Warszawa 1995.

Raś M., Austria w polityce zagranicznej Federacji Rosyjskiej (Austria in the Foreign Policy of the Russian Federation), "Studia Politica Germanica" 2014.

Schaub A.R., Neutralität und kollektive Sicherheit: Gegenüberstellung zweier unvereinbarer Verhaltenskonzepte in bewaffneten Konflikten und These zu einem völkerrechtsgemässen mo-dus vivendi. Schriftenreihe des Institutes für Internationales Recht und Internationale Bezie-hungen (Neutrality and 
collective security: juxtaposition of two incompatible behavioral concepts in armed conflicts and thesis on a modus vivendi in accordance with international law. Publication series of the Institute for International Law and International Relations), Juristische Fakultät der Universität Basel, Basel, Frankfurt am Mein 1995.

Schindler D., Sieben Thesen zur Neutralität (Seven theses on neutrality), in: Sicherheitspolitik der Schweiz nach dem Fah-restausenden. Sieben Thesen zur künftigen Selbstbehauptungsstrategie der Schweiz (Switzerland's security policy after millennia. Seven theses on Switzerland's future self-assertion strategy), ed. G.G. Heliberger, Zürich 1997.

Schmidt P., Die neunen EU - Mitglieder Finnland, Österreich und Schweden, vor der Regie-rungskonferenz 1996. Sicherheitspolitische Ambivalenzen (The new EU members Finland, Austria and Sweden, before the 1996 IGC. Security policy ambivalences), Stiftung Wissenschaft und Politik, Ebenhausen 1995.

Schmidt P., Edthofer J., Die EU ALS Sicherheits- und Verteidigungsunion: Das Meinungsbild der ÖsterreicherInnen im Vergleich (The EU as a security and defense union: the opinion of Austrians in comparison), „ÖGIE, Policy Brief", no. 20/2018.

Sicher. Und morgen? Sicherheitspolitische Fahresbericht 2019 (For sure. And tomorrow? Security policy annual report 2019), Direktion für Sicherheitspolitik, Bundesministerium Landesverteidigung, Wien 2018.

Sicherheits- und Verteidigungsdoktrin. Analyse-Teil. Bericht an der Nationalrat (Security and Defense Doctrine. Analysis part. Report to the National Council), Verfasst von einer Expertenkommission im Auftrag der Bundesregierung 23.01.2001, Wien 2002.

Skuhra A., Österreichische Sicherheitspolitik (Austrian security policy), in: Politik in Österreich. Das Handbuch (Politics in Austria. The handbook), eds. H. Dachs Gehrlich, P. Gottweiss, H. Kramer, H. Lauber, W.C. Müller, E. Talos, Mans, Wien 2006.

Verdross A., Simma B., Universelles Völkerrecht (Universal international law), Duncker \& Hublot, Berlin 1984.

Zemanek K., The Changing International System A New Look a the Collective Security and Permanent Neutrality, "Austrian Journal of Public and International Law", no. 42/1991. 